\title{
New Records of Rare Psychrolutid Fishes (Psychrolutidae) in the Sea of Okhotsk
}

\author{
P. A. Saveliev* \\ National Scientific Center for Marine Biology, Far Eastern Branch, \\ Russian Academy of Sciences (NSCMB FEB RAS), Vladivostok, Russia \\ *e-mail: tomthumb@mail.ru \\ Received January 15, 2021; revised January 25, 2021; accepted January 27, 2021
}

\begin{abstract}
Two rare species of psychrolutid fish (Psychrolutidae) were found in the Sea of Okhotsk. Psychrolutes dolganovi was found at a depth of $142 \mathrm{~m}$ near Urup Island (southern Kuril Islands); earlier the species was known only from the holotype collected off the Pacific coast of Iturup Island. This species is recorded in the Sea of Okhotsk for the first time. P. pustulosus was collected at depths of 205-400 m along central part of Kuril Islands and in the northwestern part of the Sea of Okhotsk at depths of 240-294 m. A key to the species of the genus Psychrolutes inhabiting the northern Pacific Ocean is presented.
\end{abstract}

Keywords: Psychrolutes dolganovi, Psychrolutes pustulosus, geographic range, zoogeography, Sea of Okhotsk DOI: $10.1134 / \mathrm{S} 0032945221050143$

\section{INTRODUCTION}

According to Nelson (Nelson, 1982; Jackson and Nelson, 1998), the genus Psychrolutes includes 12 species, more than half of them inhabit the North Pacific (Nelson, 1982; Fricke, 1990; Mecklenburg et al., 2002; Nakabo, 2002; Parin et al., 2014). P. dolganovi Mandrytsa, $P$. paradoxus Günther, $P$. pustulosus (Schmidt), P. phrictus Stein et Bond are known from the waters of the Sea of Okhotsk (Mandritsa, 1993; Fedorov, 2000; Sheiko and Fedorov, 2000). Among the listed species, only $P$. phrictus reaches a total length $(T L)$ of $70 \mathrm{~cm}$ and is considered a common species, while the maximal $T L$ of other species does not exceed $120 \mathrm{~mm}$. This is the reason why they are relatively rarely caught by trawls and dredges and, therefore, their morphology and zoogeography remain poorly studied. Recently redescribed pimpled sculpin P. pustulosus has been studied the most completely (Nazarkin et al., 2014). The range of this species covers the northern Sea of Japan and the Sea of Okhotsk, including the southern Kuril Islands (Yabe et al., 1995; Nazarkin et al., 2014). It is reported that this species is found in the waters of the western Kamchatka, the northern and central Kuril Islands (Sheiko and Fedorov, 2000), but in fact these data have not been confirmed, and the material has obviously not been preserved. Dolganov's sculpin $P$. dolganovi (Mandrytsa) is another representative of the family, apparently the rarest in the northern Pacific Ocean, known from the moment of description by a single specimen $S L 35.5 \mathrm{~mm}$ caught near the southern Kuril Islands. This study describes new finds of these two rare representatives of the family Psycholutidae in the Sea of Okhotsk.

\section{MATERIALS AND METHODS}

New data on the distribution and ecology of P. dolganovi and $P$. pustulosus were obtained during two expeditions in the Sea of Okhotsk in August-September 2013 onboard the R/V Akvaresurs (A) (fishing bottom trawl 27.1/24.4) and in June-August 2019 onboard the R/V Akademik Oparin (AO) (beam trawl).

The following abbreviations are adopted in the text: $S L$-standard length; $D, A, P, V, C$-dorsal, anal, pectoral, ventral, and caudal fins, respectively; canals of the seismosensory system: $\mathrm{CSO}$-supraorbital, $\mathrm{CIO}-$ infraorbital, $C P O$ - postorbital, $C T$-occipital, $C P M-$ preoperculomandibular, $C L L-$ trunk, $C C$-coronal pore; ZIN-collection of the Zoological Institute of the Russian Academy of Sciences (St. Petersburg, Russia), MIMB-Museum of the National Scientific Center for Marine Biology of the Far Eastern Branch of the Russian Academy of Sciences (Vladivostok, Russia). The number of vertebrae and rays in unpaired fins was calculated from radiographs made using a Faxitron $M X$-20X-ray machine.

\section{RESULTS AND DSCUSSION Psychrolutes dolganovi (Mandrytsa)— Dolganov's sculpin}

(Fig. 1)

M a t e r i a l. MIMB 40773-1 ind. SL $29 \mathrm{~mm}, \mathrm{R} / \mathrm{V}$ AO, station no. 7, June 28, 2019, The Sea of Okhotsk, Kuril Islands, Urup Island, $45^{\circ} 52^{\prime} \mathrm{N} 149^{\circ} 37^{\prime} \mathrm{E}$, depth 142 m, boulders; collector P.A. Saveliev. 


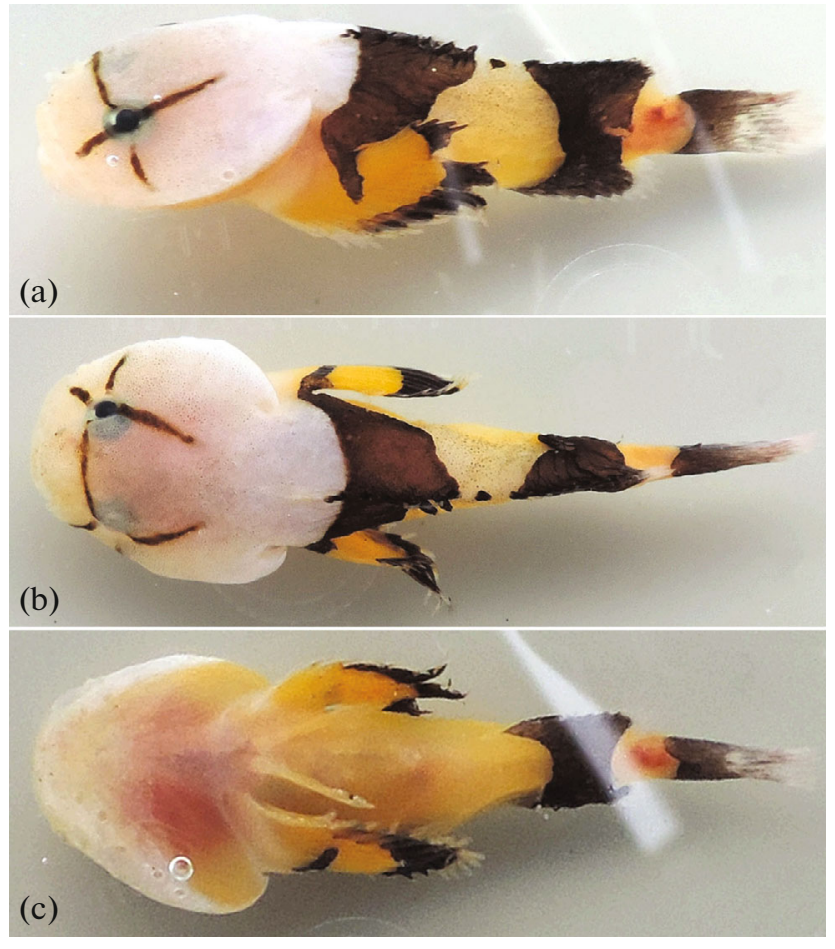

Fig. 1. Dolganov's sculpin Psychrolutes dolganovi MIMB 40773, SL 29 mm: (a) side view, (b) dorsal view, (c) ventral view.

D e s c ription. The body has three distinct wide dark stripes against a light background, one of which descends from $D 1$ to the base of $P$, the second, from $D 2$ to $A$, the third is located on the caudal fin (Figs. 1a, 1b). A dark wide transverse stripe runs along the distal edge of the light pectoral fin. A narrow dark stripe stretches through the eye orbit, without reaching the eye, from its antero-inferior margin to the supraposterior one. There are 12 main unbranched rays in $C$. The peritoneum is light (Fig. 1c). There are small supraorbital barbels.

Meristic characters: $D X 17, A 13, P 18, V$ I 3, $C 8+6+6+5$; gill rakers $0+7$; branchiostegal rays 7 (3 anterior rays are longer than following four rays); number of vertebrate with urostyle $14+21=35$; 14 pairs of epipleuralia (two anterior pairs are thicker than following). Pleuralia are absent. 13 pores in $C L L$. On the upper part of the head, the number of pores is reduced: there are no pores in the frontal and occipital commissures, in $C T$ and $C S O$, between the nasal and frontal bones, and in the area of the $C I O$ and $C P M$ junction. Number of pores as in type specimen: $C P M$ 8, CIO 5, CSO 1.

M e a surements, as \% $S L$ : head length 44.8 , snout length 12.4, horizontal orbital diameter 8.6, postorbital distance 23.8, interorbital distance 13.8, upper jaw length 17.2, lower jaw length 18.9, antedorsal distance 43.4, antepectoral distance 42.1, anteventral distance 31.4, anteanal distance 53.4, caudal peduncle length 9.7, maximum body height 20.7, caudal peduncle height 8.9 , distance from base of pelvic fin to anus 25.2, distance from anus to beginning of anal fin 15.6 , pectoral fin length 34.8 , pectoral fin base length 16.2 , pelvic fin length 23.1 , base length of dorsal fin 52.7, maximum dorsal fin height 8.2, anal fin base length 16.9, caudal fin length 27.6, gill slit height 18.9.

Live coloration. The upper part of the head and the occipital region, up to the beginning of the dorsal fin, are white with a barely noticeable yelloworange tint in the snout area, covered with small brown specks. The area of the operculum membranes is light yellow. The background color of the body is yellowishorange, the body is crossed by two wide dark brown stripes. The first one descends obliquely from the 2 nd-8th ray of $D 1$ to the upper part of the base of $P$, covering the bases of several upper rays. The second stripe covers rays $12-20$ of $D 2$, from where it extends to the entire anal fin. A dark brown stripe runs along the distal edge of $P$. Caudal fin is dark brown in front. Distal parts of rays $P, D 2, A$, and $C$ are white. The coloration of the head of specimen MIMB 40773 is somewhat different from that described for holotype ZIN 50136. A narrow longitudinal dark stripe passes through the eye backward from the 4th pore of the $C I O$. Another similar stripe runs transversely through both eyes to the 6th pore of the CPM. At the intersection in the eye area, both stripes form a cruciform pattern, which is absent in the type specimens. In the fixed specimen, the yellow-orange tones of color have disappeared; dark stripes are preserved.

N o t e s. Specimen MIMB 40773 generally corresponds to the original description, but has no tubercles on the skin at all, probably due to the dimensional variability of this trait (the holotype is larger). P. dolganovi differs from the representatives of the genus Psychrolutes inhabiting the northern Pacific Ocean by the combination of a unique coloration of three contrasting dark stripes on a light background of the body (two on the body and one on the caudal fin), a special coloration of the head, and the presence of supraorbital barbels. It is most similar to $P$. paradoxus and $P$. pustulosus by the structure of the caudal fin (the number of main rays, the shape and relative position of the bones of the hypural complex, and the shape of the processes of the second pre-caudal vertebra) (Jackson, Nelson, 1998; Nazarkin et al., 2014)

Distribution and ecology. Known from the waters of the Kuril Islands, where it was found off the Pacific coast of Iturup Island (ZIN 50136: September $28,1987,44^{\circ} 37^{\prime} 48^{\prime \prime} \mathrm{N} 146^{\circ} 55^{\prime} \mathrm{E}$ ) and off the Sea of Okhotsk coast of Urup Island at depths of 142$200 \mathrm{~m}$. The new find makes it possible to consider the species as part of the fauna of the Sea of Okhotsk. Sampled with Kasatkia memorabilis Soldatov et Pavlenko, Bryozoichthys lysimus (Jordan et Snyder), Icelus gilberti Taranetz, and Thyriscus anoplus Gilbert et Burke. Of the accompanying forms, the most import- 
ant place in the catch was occupied by the mass species of sponges of the class Demospongiae: that form the benthic community. (Lissodendoryx oxeota Koltun, Mycale adhaerens (Lambe), Wigginsia wigginsi de Laubenfels, Monanchora pulchra (Lambe), Haliclona spp., and Homaxinella subdola (Bowerbank)).

$P$. dolganovi is probably the smallest of the psychrolutids; its length $(S L)$ does not exceed $35.5 \mathrm{~mm}$.

\section{Psychrolutes pustulosus (Schmidt)—pimpled sculpin}

(Fig. 2)

$\mathrm{M}$ a t e r i a 1 . MIMB 40774-1 ind. SL $34 \mathrm{~mm}, \mathrm{R} / \mathrm{V}$ AO, station no. 22, July 3, 2019, the Sea of Okhotsk, Kuril Islands, Simushir Island, $47^{\circ} 15^{\prime} \mathrm{N} 152^{\circ} 10^{\prime} \mathrm{E}$, depth 205-222 m, gravel, collector P.A. Saveliev; MIMB 40775-1 ind. SL $52 \mathrm{~mm}$, R/V AO, station no. 81, August 16, 2019, the Sea of Okhotsk, Kuril Islands, Raikoke Island, $48^{\circ} 20^{\prime} \mathrm{N} 153^{\circ} 11^{\prime} \mathrm{E}$, depth $241-$ $400 \mathrm{~m}$, pebble and boulders, collector P.A. Saveliev; MIMB 40776-4 ind. SL 41-85 mm, R/V A, station no. 165, September 14, 2013, the Sea of Okhotsk, $57^{\circ} 00^{\prime} \mathrm{N} 144^{\circ} 40^{\prime} \mathrm{E}$, depth $264 \mathrm{~m}$, collector P.A. Saveliev; MIMB 40777-5 ind. SL 47-67 mm, R/V A, station no. 166, September 14, 2013, the Sea of Okhotsk, $57^{\circ} 00^{\prime} \mathrm{N} \quad 145^{\circ} 00^{\prime} \quad \mathrm{E}$, depth $240 \mathrm{~m}$, collector P.A. Saveliev; MIMB 40778-2 ind. SL $66 \mathrm{~mm}$ and $67 \mathrm{~mm}, \mathrm{R} / \mathrm{V} \mathrm{A}$, station no. 170, September 16, 2013, the Sea of Okhotsk, $56^{\circ} 45^{\prime} \mathrm{N} 144^{\circ} 41^{\prime} \mathrm{E}$, depth $287 \mathrm{~m}$, collector P.A. Saveliev; MIMB 40779- 1 ind. $S L$ $61 \mathrm{~mm}, \mathrm{R} / \mathrm{V}$ A, station no. 182, September 20, 2013, the Sea of Okhotsk, $56^{\circ} 30^{\prime} \mathrm{N} 144^{\circ} 20^{\prime} \mathrm{E}$, depth $294 \mathrm{~m}$, collector P.A. Saveliev; MIMB 40780- 2 ind. $S L$ $60 \mathrm{~mm}$ and $69 \mathrm{~mm}, \mathrm{R} / \mathrm{V} \mathrm{A}$, station no. 184, September 21, 2013, the Sea of Okhotsk, $56^{\circ} 30^{\prime}$ N $145^{\circ} 00^{\prime}$ E, depth 264 m, collector P.A. Saveliev.

Meristic characters (mean and standard deviation are given in brackets). D1 VII-VIII (7.3 \pm 0.49), D2 17-19 (18.1 \pm 0.83$), A 15-16(15.4 \pm 0.51)$, $P$ 15-17 (15.9 \pm 0.49$), V$ I $3, C 4-5+7+7+4-5$; gill rakers $2-4+10-14(14.2 \pm 1.48)$, branchiostegal rays 7 , vertebrae (with urostyle) $11-13+19-22=32-34$ $(32.9 \pm 0.69)$. Very large pores in $C L L 10-13(11.0 \pm$ 1.08). All head canals usually have pores, their number is maximum in genus Psychrolutes: CSO 2, CC 0-1 (0.9); $C I O 7-8$ (7.1 \pm 0.26$), C P O 2-3(2.9 \pm 0.26) ; C T$ $0-3(1.1 \pm 1.06), C P M 9$ (two pores on the chin). The diameter of some of the pores of the $C P M$ and $C L L$, located closer to the base of $C$, is not less than the pupil diameter.

Color at io n. In live specimens, the upper part of the body and fins are pink, sometimes with an admixture of gray; the belly and several lower rays of $P$ are light white-pink, the peritoneum is dark gray (Fig. 2). Fixed specimens are light gray or white with dark gray peritoneum.

Notes. The fish from the northern Sea of Okhotsk have less pronounced skin tubercles compar-

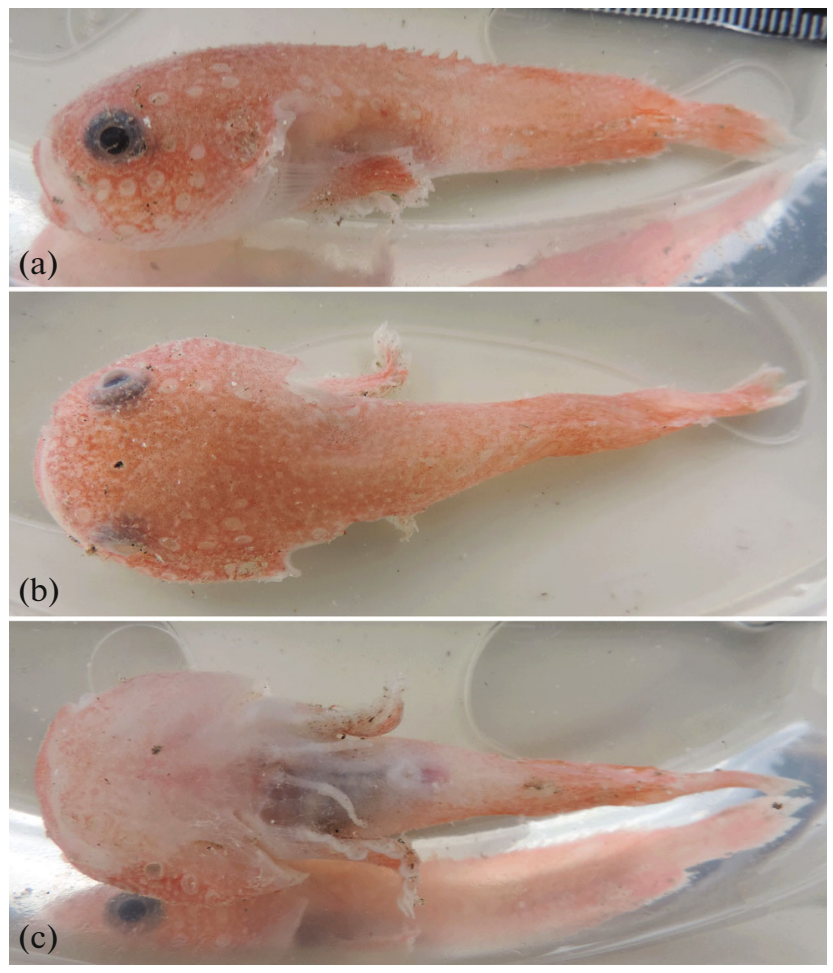

Fig. 2. Pimpled sculpin Psychrolutes pustulosus MIMB 40775, SL 52 mm: (a) side view, (b) dorsal view, (c) ventral view.

ing to the individuals from the waters of the Kuril Islands: in the first, the tubercles are located lower and less frequently. There is a dimensional variability of the cutaneous tubercles, which are well developed on the head, belly, and rays of unpaired fins in large specimens in comparison with small ones, in which the cutaneous tubercles are very weakly developed and are noticeable only at the base of $P$ (MIMB 40774-SL $34 \mathrm{~mm}$ ) or absent (MIMB 40776-SL $41 \mathrm{~mm}$ ).

Distribution and ecology. New finds expand the range of the species in the northwestern Sea of Okhotsk almost to Iona Island, and in the waters of the Kuril Islands to northward to Raikoke Island. In the waters of the central Kuril Islands at station no. 22, P. pustulosus was accompanied by Artediellus ingens Nelson, B. lysimus, Eumicrotremus fedorovi Mandrytsa, Hemilepidotus gilberti Jordan et Starks, T. anoplus; at station no. 81, by Palmoliparis beckeri Balushkin, Puzanovia rubra Fedorov, Sebastolobus macrochir (Günther) and sponges Clathria bitoxifera (Koltun), Halichondria sp., Latrunculia oparinae Samaai et Krasokhin, Melonanchora tetradentifera Koltun, Megaciella sp., Mycale sp., and Suberites sp. In the northwestern Sea of Okhotsk, at all stations, Lycogrammoides schmidti Soldatov et Lindberg $(16.1 \%$ by abundance from the calculated distribution density in ind. $/ \mathrm{km}^{2}$ ), Malacocottus zonurus Bean (15.8), Icelus armatus (Schmidt) (6.8), Lycodes pectoralis Toy- 
oshima (6.5), L. macrochir Schmidt (6.4), Artediellina antilope (Schmidt) (4.9), Careproctus rastrinus Gilbert et Burke (4.4), Bathyraja parmifera (Bean) (4.1), Dasycottus setiger Bean (3.6), C. macrodiscus Schmidt (2.9), Bothrocarina microcephala (Schmidt) (2.8), and Reinhardtius hippoglossoides (Walbaum) (1.4) were caught together with the pimpled sculpin. Sponge Aphrocallistes sp. (class Hexactinellida) was caught in significant numbers in several trawls.

The identification table of the species of the genus Psychrolutes, inhabiting the northern Pacific Ocean from the southeast Japan to the Pacific coast of North America is presented below, compiled on the basis of original and literary data (Jordan, Starks, 1895; Nelson, 1980, 1982; Nelson et al., 1985; Fricke, 1990; Mecklenburg et al., 2002; Nakabo, 2002; Nazarkin et al., 2014).

\section{TAXONOMIC KEY OF THE PSYCHROLUTES SPECIES INHABITING THE NORTHERN PART OF THE PACIFIC OCEAN}

1 (10) Body coloration monotonous or almost monochromatic, except for the distal part of the rays of $P$, the coloration of latter may differ slightly from the main one; there are no distinct contrasting dark stripes on the body; some specimens reach $S L 600 \mathrm{~mm}$.

2 (5) The skin is covered with small tubercles (may be absent in fish $S L<40 \mathrm{~mm}$ ); barbels on the skin of the head are absent; membranes $D$ and $A$ pass to base of $C$, caudal peduncle not pronounced; $P$ 14-18; $S L<$ $100 \mathrm{~mm}$.

3 (4) There are large pores in the coronal and occipital commissures; the posterior pore of the trunk canal is at the base of $C$; the pectoral fin reaches the beginning of the base of $A$; gill rakers 10-18 (Sea of Okhotsk and the northern part of Japan; 208-620 m).

\section{P. pustulosus}

4 (3) There are no pores in the coronal and occipital commissures; the last pore of the trunk canal is on rays $C$; the pectoral fin reaches the middle of the base of $A$; gill rakers 8-13 (southwestern Bering Sea, Commander and Aleutian Islands, along the Pacific coast of North America southward to Puget Sound (USA); $0-225 \mathrm{~m})$

$P$. sigalutes

5 (2) There are no tubercles on the skin; the head may be covered with small barbels; $D$ and $A$ are not connected by the membrane to the base of $C$, the caudal peduncle is well expressed; $P$ 19-26 (usually 2225); $S L$ up to $400-600 \mathrm{~mm}$.

6 (7) The mouth is small, the upper jaw does not reach the vertical line of the anterior edge of the eye; one pore on the chin (Tosa Bay (east coast of Japan), New Zealand; 945-1043 m). P. microporos

7 (6) The mouth is large, the upper jaw extends beyond the vertical line of the anterior edge of the eye; there are two pores on the chin.
8 (9) The head is covered with small barbels; there are pores of the trunk canal of the seismosensory system (from the Pacific coast of the northern Japan to the southern California, USA; 480-2800 m) ...

P. phrictus

9 (8) Barbels on the head and pores of the trunk canal of the seismosensory system are absent (from Tosa Bay to Mie Prefecture (Eastern Japan), South Africa; 550-1010 m) P. macrocephalus

10 (1) The color of the body is not monotonous, there are contrasting stripes or spots of different shapes; body length does not exceed $S L \leq 70 \mathrm{~mm}$.

11 (12) The body is crossed by three wide, clearly outlined dark stripes on a light background; posterior third of $P$ is dark, except for ray tips; at least one dark narrow stripe obliquely passes through the eye orbit from its anteroposterior margin to its upper posterior margin; $P 18$ (Kuril Islands; 142-200 m).

P. dolganovi

12 (11) The color is different; there are dark stripes and spots of various shapes on the body; the posterior third of $P$ is light; $P$ 19-23 (usually 22) (Sea of Japan, Sea of Okhotsk, Bering Sea, along the Pacific coast of North America southwards off Puget Sound, USA; 0$240 \mathrm{~m})$

P. paradoxus

\section{ACKNOWLEDGMENTS}

The author is grateful to the participants of the expedition on the R/V Akvaresurs and in the $56^{\text {th }}$ cruise of the R/V Akademik Oparin for their help with the analysis of catches. Special thanks to V.A. Shilov (NSCMB FEB RAS) for the information on the taxonomic composition of sponges and to O.S. Voskoboinikova (Zoological Institute, Russian Academy of Sciences) for a critical analysis of the manuscript.

\section{FUNDING}

The expedition to the Kuril Islands was organized with the financial support of the Ministry of Science and Higher Education of the Russian Federation and supported by grant no. 13.1902.21.0012, agreement no. 075-15-2020-796.

\section{COMPLIANCE WITH ETHICAL STANDARDS}

Conflict of interests. The author declares that he has no conflict of interests.

Statement on the welfare of humans or animals. All applicable international, national, and/or institutional guidelines for the care and use of animals were followed.

\section{OPEN ACCESS}

This article is licensed under a Creative Commons Attribution 4.0 International License, which permits use, sharing, adaptation, distribution and reproduction in any medium or format, as long as you give appropriate credit to 
the original author(s) and the source, provide a link to the Creative Commons license, and indicate if changes were made. The images or other third party material in this article are included in the article's Creative Commons license, unless indicated otherwise in a credit line to the material. If material is not included in the article's Creative Commons license and your intended use is not permitted by statutory regulation or exceeds the permitted use, you will need to obtain permission directly from the copyright holder. To view a copy of this license, visit http://creativecommons.org/licenses/by/4.0/.

\section{REFERENCES}

Fedorov, V.V., Species composition, distribution and depths of habitat of fish-like and fish species of the northern Kuril Islands, in Promyslovo-biologicheskie issledovaniya ryb v tikhookeanskikh vodakh Kuril'skikh ostrovov i prilezhashchikh raionakh Okhotskogo i Beringova morei v 1992-1998 gg. (Commercial and Biological Studies of Fishes in Pacific Waters of Kuril Islands and Adjacent Regions of the Okhotsk and Bering Seas in 1992-1998), Moscow: VNIRO, 2000, pp. 7-41.

Fricke, R., A new species of psychrolutid fish from Western Australia, Jpn. J. Ichthyol., 1990, vol. 36, no. 4, pp. 404409.

https://doi.org/10.11369/jji1950.36.404

Jackson, K.L. and Nelson, J.S., Ambophthalmos, a new genus for "Neophrynichthy" angustus and "Neophrynichthys" magnicirrus, and the systematic interrelationships of the fathead sculpins (Cottoidei, Psychrolutidae), Can. J. Zool., 1998, vol. 76, no. 7, pp. 1344-1357.

https://doi.org/10.1139/z98-053

Jordan, D.S. and Starks, E.C., The fishes of Puget Sound, Proc. Calif. Acad. Sci., 1895, vol. 2, no. 5, pp. 785-852.

Mandritsa, S.A., New species of genus Gilbertidia (Scorpaeniformes, Psychrolutidae) from Kuril Islands area, Vopr. Ikhtiol., 1993, vol. 33, no. 2, pp. 288-290.

Mecklenburg, C.W., Mecklenburg, T.A., and Thorsteinson, L.K., Fishes of Alaska, Bethesda: Am. Fish. Soc., 2002.
Nakabo, T., Psychrolutidae. Tadpole sculpins, in Fishes of Japan with Pictorial Keys to the Species, Nakabo, T., Ed., Tokyo: Tokai Univ. Press, 2002, pp. 651-653, 1528-1530.

Nazarkin, M.V., Voskoboinikova, O.S., and Balanov, A.A., The distribution, morphology, and taxonomic position of Psychrolutes pustulosus (Schmidt, 1937) (Scorpaeniformes: Psychrolutidae), Russ. J. Mar. Biol., 2014, vol. 40, no. 3, pp. 177-187.

Nelson, J.S., Psychrolutes sio, a new psychrolutid fish (Scorpaeniformes) from the southeastern Pacific, Can. J. Zool., 1980, vol. 58, no. 3, pp. 443-449.

https://doi.org/10.1139/z80-058

Nelson, J.S., Two new South Pacific fishes of the genus Ebinania and contributions to the systematics of Psychrolutidae (Scorpaeniformes), Can. J. Zool., 1982, vol. 60, no. 6 , pp. $1470-1504$.

https://doi.org/10.1139/z82-196

Nelson, J.S., Chirichigno, N., and Balbontsín, F., New material of Psychrolutes sio (Scorpaeniformes, Psychrolutidae) from the eastern Pacific of South America and comments on the taxonomy of Psychrolutes inermis and Psychrolutes macrocephalus from the eastern Atlantic of Africa, Can. J. Zool., 1985, vol. 63, no. 2, pp. 444-451.

https://doi.org/10.1139/z85-063

Parin, N.V., Evseenko, S.A., and Vasil'eva, E.D., Ryby morei Rossii: annotirovannyi katalog (Fishes of Russian Seas: Annotated Catalogue), Moscow: KMK, 2014.

Sheiko, B.A. and Fedorov, V.V., Class Cephalospidomorphi. Class Chondichthyes. Class Holocephali. Class Osteichthyes, in Katalog pozvonochnykh Kamchatki $i$ sopredel'nykh morskikh akvatorii (Catalogue of Vertebrates of Kamchatka and Adjacent Waters), Petropavlovsk-Kamchatskiy: Kamchat. Pechat. Dvor, 2000, chap. 1, pp. 7-69.

Yabe, M., Tsutsui, D., Shimokawa, T., and Kinoshita, T., A psychrolutid fish, Psychrolutes pustulosus, collected from the southwestern Okhotsk Sea off Hokkaido, Japan, Jpn. J. Ichthyol., 1995, vol. 42, no. 2, pp. 200-202.

Translated by D. Martynova 